\title{
AN ASSESSMENT OF THE INCIDENCE OF POVERTY AMONG RURAL ACTIVE POPULATION IN MANGU LOCAL GOVERNMENT AREA, PLATEAU STATE, NIGERIA
}

\author{
Dakyes, S. P. and Mundi, R.
}

http://dx.doi.org/10.4314/ejesm.v6i1.5

Received 7th September 2012; accepted 10th January 2013

\begin{abstract}
The study investigated the incidence and spatial distribution of poverty among rural active population in Mangu Local Government of Plateau State, Nigeria. The objectives of the study were to determine the socio-demographic and economic characteristics of the respondents; the incidence and spatial distribution of poverty and the causes of poverty in the study area. A sample size of 500 was adopted for the study. The study area comprised of 11 districts and over 260 settlements. Five districts and 25 settlements were selected using the random and systematic sampling techniques. The questionnaire, focus group discussions and in-depth interviews were used as tools for data collection from the respondents. The data were analyzed using different statistical techniques such as descriptive, correlation analyses as well as ANOVA. The finding reveals that there is high and spatial variation in level of poverty in the study area. Many reasons were identified to have influenced poverty in the study area such as failure of agriculture due to high cost of farm inputs, crises, decline of tin mining activity in the study area as well as low level of education, and low income among others. Recommendations were made for policy makers and implementers to empower the rural areas and enhance the development of the country side.
\end{abstract}

Keyword: Incidence, Poverty, Rural, Active Population

\section{Introduction}

The interrelationship between population and development cannot be over emphasized. Population is a major component of development. Development affects population and population in turns affects the process of development in a society. However, population can only play such vital role of facilitating the process of development when it's economic and infrastructural based upon which it draws its strength from, is enhanced. Lack of a strong and viable economic base and solid infrastructure has continued to drag the population into abject poverty making it difficult for the population to play its role as a pivot in the development process of communities. The challenges posed to humanity by poverty have persisted since the history of man. Okeke, (2007), observes that, no country can rightly claim to be developed when the poverty level among its populace is not kept and sustained at the lower ebb.

Specific economic conditions in rural areas result in fewer development opportunities being available where agriculture is generally the most important economic sector, than in urban locations. This situation makes rural areas highly dependent on the performance of a single crop where investments are risky due to weather and other conditions. In addition, rural areas are often politically marginalized leaving little opportunity for the poor to influence government policies regarding what they produce. In many of the developing countries, policies have consistently discriminated against agriculture. These policies negatively affect agricultural performance together with the rural economic base, resulting in net transfer of resources out of rural areas (Kirubi, 2005). These may be reasons for high incidence of poverty and low level of development in most rural areas of developing countries, including Nigeria. Globally, extreme poverty continues to be a rural phenomenon despite increasing urbanization, as $75 \%$ of the world's extremely poor live in rural areas and depending on agriculture for survival (Gustavo et al., 2007; Ravallion et al., 2007; UNECA 2005 and FAO 2005). It is argued that the promotion of rural economy in a sustainable way has the Potential of increasing employment opportunities in rural areas. It will also reduce regional income disparities, stemmed pre-mature rural-urban 
migration and ultimately reduce poverty at its very source.

While there is a considerable amount of literature on poverty and related issues in Nigeria, very little information exists regarding poverty dynamics over time, particularly for rural Nigerian households. The existing literature in the area of poverty reduction in Nigeria, such as Olayemi (1995); Yusuf (2000); Ogwumike (2000); Adeyeye, (2000); Ogwuche (2008); World Bank (1995,2000);WBR (2001); Obadan (1995); Onibokun and Kumuyi(1996); Aigbokhan (1991,2001;2007); Canagarajah et al (1997);NBS (2005, 2006); Omonona, (2000); Olaniyan, (2003) and Okunmadewa et al., 2005), focused on poverty alleviation from the standpoint of economic growth, basic needs, employmentoriented, sectoral and rural development, and access to physical capital, the perspective of public needs, safety nets, good governance and political considerations. None of these studies investigated the dynamics of rural poverty and most importantly, rural poverty in Nigeria.
This study therefore assessed the incidence of poverty among active rural population in Mangu area of plateau state, Nigeria. It sought to find answers to the following questions:

* What are the socio-demographic characteristics of the active population in the study area?

* What are the causes of poverty in the study area? The objectives of the study are to:

- Identify the socio-demographic and economic characteristics of the respondents in the study area;

- Determine the incidence and spatial distribution of poverty in the study area;

- Investigate the determinants of poverty in the study area

\section{Study Area}

Mangu Local Government is located between latitude $9^{\circ} 00^{\prime} \mathrm{N}$ and $9^{\circ} 45^{\prime} \mathrm{N}$ and Longitude $9^{\circ}$ $05^{\prime} \mathrm{E}$ and $9^{\circ} 15^{\prime} \mathrm{E}$ (Figure.1). It has a total land area of about $2,413 \mathrm{~km}^{2}$ and a total population of 294,931 in 2006 (NPC, 2007).

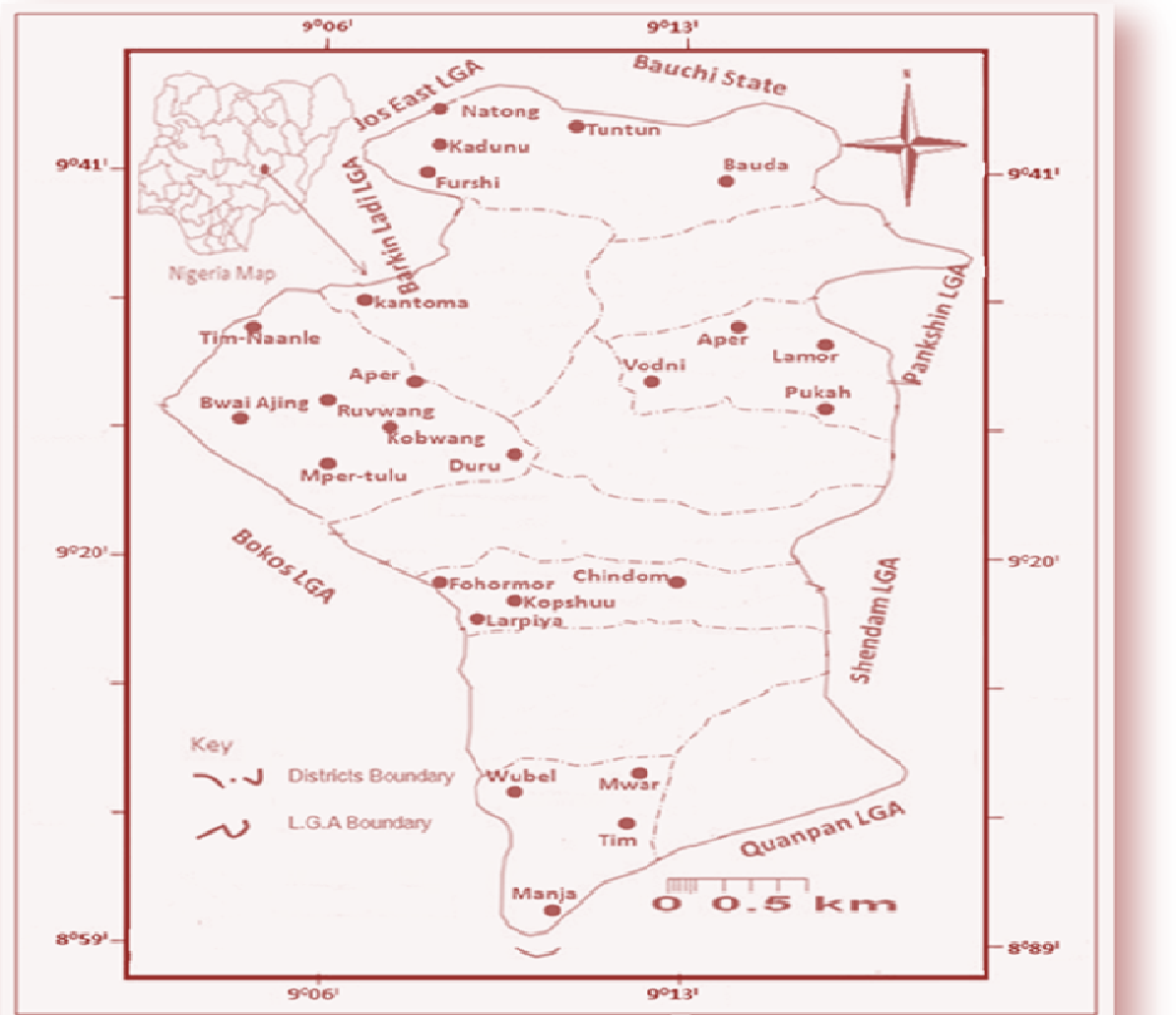

Figure 1 Mangu Local Area Showing Study Settlements Source: GIS Lab University of Abuja (2010) 


\section{Methodology}

The Mangu-Local Government Area of Plateau State is made up of 11 districts, comprising of over 260 settlements. A multi-stage sampling technique was used in the selection of the settlements and sample population. The first stage involved random selections in which five districts were selected (Table 1).

The second stage involves an alphabetical listing of all the settlements in the selected five districts after which 25 settlements were selected using the systematic sampling technique. The third stage involve a listing exercise of households in each of the 25 settlements considered above from which a total of 500 household heads were selected using the systematic sampling technique representing about $15 \%$ of the household heads population in the study area. The first household head was picked randomly in each of the 25 settlement after which an interval of 5 was maintained (that is, every fifth household head was selected). Questionnaires were then administered to each of the 500 household heads. To obtain information about those who were affected by the decline of the mining activities, a Focus Group Discussions (FGDs) involving some selected members of the community was organised in addition to questionnaire administration.

Other instruments that were used in collecting data from the respondents in the study area - included in-depth interviews with head of each settlement being the custodian of the people. The Focus Group Discussions were held in each of the 25 settlements.

Table 1 Selected districts and Settlements

\begin{tabular}{lllll}
\hline District & $\begin{array}{l}\text { No of } \\
\text { settlements }\end{array}$ & $\begin{array}{l}\text { No of } \\
\text { settlements } \\
\text { Selected }\end{array}$ & $\begin{array}{l}\text { Household heads } \\
\text { Population in the 25 } \\
\text { selected settlements }\end{array}$ & No of Respondents \\
\hline Langai & 21 & 5 & 521 & 78 \\
Kombun & 30 & 7 & 857 & 129 \\
Pushit & 19 & 4 & 547 & 82 \\
Chakfem & 17 & 4 & 536 & 80 \\
Ampang-West & 16 & 4 & 675 & 101 \\
Mangu & 27 & 1 & 202 & 30 \\
Total & 130 & 25 & 3,338 & 500 \\
\hline
\end{tabular}

\section{Result and Analysis}

Socio-Demographic and Economic Characteristics of Respondents

Table 2 below shows the socio-demographic and economic characteristics of the respondents.

Table 2 Socio-Demographic Characteristic of Respondents by Districts

\begin{tabular}{|c|c|c|c|c|c|c|c|c|c|c|c|c|c|c|}
\hline \multirow[t]{2}{*}{ Characteristics } & \multicolumn{2}{|c|}{ Kantoma } & \multicolumn{2}{|c|}{ Ampang } & \multicolumn{2}{|c|}{ Kombun } & \multicolumn{2}{|c|}{ Langai } & \multicolumn{2}{|c|}{ Pushit } & \multicolumn{2}{|c|}{ Chakfem } & \multicolumn{2}{|c|}{ Total } \\
\hline & No & $\%$ & No & $\%$ & No & $\%$ & No & $\%$ & No & $\%$ & No & $\%$ & No & $\%$ \\
\hline Sex & & & & & & & & & & & & & & \\
\hline Male & 22 & 73.3 & 70 & 75.3 & $\begin{array}{l}10 \\
1\end{array}$ & 80.2 & 56 & 72.7 & 56 & 68.3 & 53 & 66.2 & 358 & 73.4 \\
\hline $\begin{array}{l}\text { Female } \\
\text { Age }\end{array}$ & 8 & 26.7 & 23 & 24.7 & 25 & 19.8 & 21 & 27.3 & 26 & 31.7 & 27 & 33.8 & 130 & 26.6 \\
\hline 15.34 & 4 & 13.3 & 9 & 9.7 & 17 & 13.5 & 8 & 23.4 & 7 & 8.5 & 10 & 2.5 & 65 & 13.3 \\
\hline $35-49$ & 1 & 3.3 & 20 & 21.5 & 34 & 27.0 & 13 & 16.9 & 15 & 18.3 & 18 & 22.5 & 101 & 20.7 \\
\hline $50-59$ & 13 & 43.3 & 23 & 24.7 & 30 & 23.8 & 16 & 20.8 & 26 & 31.7 & 21 & 26.2 & 129 & 26.4 \\
\hline $60-64$ & 12 & 40.0 & 14 & 15.1 & 30 & 23.8 & 22 & 28.6 & 23 & 28.0 & 21 & 26.2 & 122 & 25.0 \\
\hline $\begin{array}{l}65+ \\
\text { Marital status }\end{array}$ & - & - & 27 & 29.0 & 15 & 11.9 & 8 & 10.4 & 11 & 13.4 & 10 & 12.5 & 71 & 14.5 \\
\hline Single & - & - & 1 & 1.1 & 1 & 0.8 & 1 & 1.3 & - & - & 1 & 1.2 & 4 & 0.8 \\
\hline Married & 27 & 90.0 & 73 & 78.5 & $\begin{array}{l}11 \\
5\end{array}$ & 91.3 & 71 & 92.3 & 74 & 90.2 & 73 & 91.2 & 433 & 88.7 \\
\hline Divorced & - & - & 8 & 8.6 & 1 & 0.8 & 1. & 1.3 & 1 & 1.2 & 3 & 3.8 & 14 & 2.9 \\
\hline Widow & - & - & 5 & 5.4 & 8 & 6.3 & 4 & 5.2 & 7 & 8.5 & 3 & 3.8 & 30 & 6.1 \\
\hline
\end{tabular}




\begin{tabular}{|c|c|c|c|c|c|c|c|c|c|c|c|c|c|c|}
\hline Separated & 3 & 10.0 & 6 & 6.5 & 1 & 0.8 & - & - & - & - & - & - & 7 & 1.4 \\
\hline \multicolumn{15}{|l|}{ Family size } \\
\hline$<3$ & - & - & 5 & 5.4 & - & - & 7 & 9.1 & - & - & 5 & 6.2 & 17 & 3.5 \\
\hline $3-4$ & - & - & 7 & 7.5 & 12 & 9.5 & 18 & 23.4 & 13 & 15.9 & 8 & 10.0 & 58 & 11.9 \\
\hline $5-6$ & 9 & 30 & 21 & 22.6 & 31 & 24.6 & 8 & 10.4 & 22 & 26.8 & 17 & 21.2 & 108 & 22.1 \\
\hline $7-9$ & 12 & 40.0 & 23 & 24.7 & 38 & 30.2 & 17 & 22.1 & 23 & 28.0 & 25 & 31.2 & 138 & 28.2 \\
\hline $10+$ & 9 & 30.0 & 37 & 39.8 & 45 & 35.7 & 27 & 35.1 & 24 & 29.3 & 25 & 31.2 & 167 & 34.2 \\
\hline \multicolumn{15}{|l|}{ Educational } \\
\hline Non-formal & 22 & 73.3 & 53 & 57.0 & 56 & 44.4 & 40 & 51.9 & 43 & 52.4 & 40 & 50.0 & 254 & 52 \\
\hline Primary & 3 & 10.0 & 14 & 15.1 & 21 & 16.7 & 23 & 29.9 & 25 & 30.5 & 14 & 17.5 & 100 & 20.5 \\
\hline Junior secondary & 3 & 10.0 & 8 & 8.6 & 10 & 7.9 & 3 & 3.9 & 2 & 2.4 & 6 & 7.5 & 35 & 6.6 \\
\hline Senior secondary & - & - & 6 & 6.5 & 28 & 22.2 & 8 & 10.4 & - & - & 14 & 17.5 & 56 & 11.5 \\
\hline Tertiary & 2 & 6.7 & 10 & 10.8 & 5 & 4.0 & 2 & 2.6 & 7 & 8.5 & 5 & 6.1 & 14 & 2.9. \\
\hline Adult education & - & - & 2 & 2.2 & 6 & 4.8 & 1 & 1.3 & 4 & 4.9 & 1 & 1.2 & 14 & 2.9 \\
\hline \multicolumn{15}{|l|}{ Main occupation } \\
\hline Farming & 29 & 96.7 & 84 & 90.3 & $\begin{array}{l}11 \\
2\end{array}$ & 88.9 & 55 & 71.5 & 69 & 84.1 & 65 & 71.4 & 414 & 84.8 \\
\hline Civil servant & - & - & 7 & 7.5 & 10 & 7.9 & 5 & 6.5 & 10 & 12.2 & 12 & 15 & 44 & 9.1 \\
\hline Trading/business & 1 & 3.3 & - & - & 2 & 1.6 & 10 & 13 & 3 & 3.37 & 1 & 1.2 & 17 & 9.1 \\
\hline Others & - & - & 2 & 2.2 & 2 & 1.6 & 7 & 9.1 & - & - & 2 & 2.5 & 13 & 2.7 \\
\hline \multicolumn{15}{|l|}{ Minor occupation } \\
\hline Mining & 14 & 46.7 & - & - & - & - & - & - & 2 & 2.4 & 5 & 6.2 & 21 & 4.3 \\
\hline Farming & - & - & 9 & 9.9 & 6 & 4.8 & 5 & 6.5 & 9 & 11.0 & 6 & 7.5 & 35 & 7.2 \\
\hline Dry season farming & 5 & 16.7 & 32 & 35.2 & 46 & 36.5 & 21 & 27.2 & 30 & 36.6 & 19 & 23.8 & 153 & 31.4 \\
\hline Artisans/handicrafts & 6 & 20.0 & 27 & 29.7 & 26 & 20.6 & 22 & 28.6 & 22 & 28.6 & 25 & 31.2 & 128 & 26.2 \\
\hline Trading/business & 5 & 16.7 & 16 & 17.6 & 18 & 14.3 & 24 & 31.2 & 16 & 19.8 & 17 & 21.2 & 96 & 19.7 \\
\hline Others & - & - & 7 & 7.7 & 27 & 21.4 & 5 & 6.5 & 6 & 7.4 & 8 & 10.0 & 59 & 12.1 \\
\hline \multicolumn{15}{|c|}{$\begin{array}{l}\text { Annual income from } \\
\text { main occupation(\#) }\end{array}$} \\
\hline Below 25,000 & - & - & 2 & 2.2 & 12 & 9.5 & 7 & 9.1 & 10 & 12.2 & 10 & 12.5 & 41 & 8.4 \\
\hline $25,001-50,000$ & - & - & 3 & 3.2 & 19 & 15.1 & 38 & 49.4 & 13 & 15.9 & 24 & 30.0 & 97 & 19.9 \\
\hline $50,001-75,000$ & 3 & 10.0 & 17 & 18.3 & 27 & 21.4 & 15 & 19.5 & 18 & 22.0 & 15 & 18.8 & 95 & 19.5 \\
\hline $75,001-100,000$ & 12 & 40.0 & 38 & 40.9 & 36 & 28.6 & 8 & 10.4 & 21 & 25.6 & 15 & 18.8 & 130 & 26.6 \\
\hline $100,001+$ & 15 & 50.0 & 33 & 35.5 & 32 & 25.4 & 9 & 11.7 & 20 & 24.4 & 16 & 20.0 & 125 & 25.6 \\
\hline \multicolumn{15}{|c|}{$\begin{array}{l}\text { Annual income from } \\
\text { minor occupation(\#) }\end{array}$} \\
\hline Below 25,000 & 1 & 3.3 & 8 & 8.7 & 16 & 12.7 & 30 & 39.0 & 11 & 13.4 & 13 & 16.2 & 84 & 17.2 \\
\hline $25,001-50,000$ & 7 & 23.3 & 11 & 12.0 & 29 & 23.0 & 30 & 39.0 & 12 & 14.6 & 24 & 30.0 & 114 & 23.4 \\
\hline $50,001-75,000$ & 14 & 46.7 & 19 & 20.7 & 24 & 19.0 & 11 & 14.3 & 20 & 24.4 & 22 & 27.5 & 110 & 22.5 \\
\hline $75,001-100,000$ & 5 & 16.7 & 23 & 25.0 & 31 & 24.6 & 4 & 5.2 & 19 & 23.2 & 14 & 17.5 & 96 & 19.7 \\
\hline $100,001+$ & 3 & 10.0 & 31 & 33.7 & 22 & 17.5 & 2 & 2.6 & 19 & 23.2 & 7 & 8.8 & 84 & 17.2 \\
\hline
\end{tabular}

This shows that households in the study area are predominantly headed by men and less than one in every ten households is headed by women. The information on the age structure of the respondents reveals that $65.9 \%$ are 50 years and above while $13.3 \%$ of them are young adult aged 15-34 years. This finding corroborates that of Dakyes (2007) in a study of rural labour force characterization in Kombun District that the young adult who are the cream of the labourforce have migrated to the urban centers in search of greener pasture leaving behind children and old. This will no doubt be one of the causes of poverty in the study area as they may be too weak to tilt the ground.
The data on the family size reveals that only $3.5 \%$ of the respondents have a family size of between 1 and 2 . While majority (62.4\%), have a family size of 7 and above. A correlation between family size and income $(\mathrm{r}=0.891)$ indicates a strong and positive relationship. This implies that large family size is an important factor for successful escape from poverty in the study area than household with small family size. Large family size provides a sturdy workforce on the farm and so responsible for the success of such families that have it. However, while some analysts emphasize benefits to rural household of having a larger number of sturdy workforces, others stressed the handicaps imposed by large 
family size (Iliffe, 1987). Krishna (2004) in a study of rural households in India has a somewhat mixed result as small family size was an important factor for $16 \%$ of households that successfully escaped from poverty. But for another $8 \%$ of these households, large family size was an important factor of success.

Data on the education shows that majority of the respondents $(52.0 \%)$ had no formal education in the study area, while only $6.4 \%$ had tertiary education. The summary of the analysis reveals that majority $(52.0 \%)$ of the labour force had no form of formal education in the study area. In most of the Focus Group Discussions, the reason cited for non formal education by the participants is lack of opportunity to go to school when they were young as their parents were either ignorance of the importance of education or did not have the means to do so.

Information on the occupational status of the respondents reveals that majority of the respondents $(84.8 \%)$ are farmers. This finding supports UNECA (2005), which stated that agriculture is the main sources of income for $90 \%$ of rural population in Africa. However, agriculture is grossly undercapitalized in the study area resulting in low total productivity. This leads to food insecurity and poverty (Place et al 2007), the implication of which is slow pace of development, and that is the situation in most of the communities in the study area. The seasonality and low output of agriculture necessitated the need for multiple occupations in the area as indicated in the table above.

The analysis of the annual income reveals that $28.3 \%$ of the population earned between $\# 25,000$ and \#50,000 per annum. This equivalent to \#68 and \#103 per day respectively which is less than the US one dollar per day extreme poverty line $(\$ 1$
$=\# 150)$. Forty six point one percent $(46.1 \%)$ of the population earned between \#50,001 and \#75,000 per annum (between \#170 and-\#240 daily which is below $\$ 2$ per day poverty line).only $25.5 \%$ of the respondents earn from $\# 100,000$ and above annually(\#300 and above per day). Going by the World Bank definition of poverty "as those living on less than two dollars a day and extreme poverty for those living on less than one dollar a day" (DFID, 2007), more than half $(74.4 \%)$ of the population in the study area is poor.

\section{Incidence and Spatial Distribution Of Poverty}

The perception of the respondents on what constitute poverty as shown in Table 3 , reveals that majority $(43.7 \%$ )of them describe poverty as lack of money to meet basic needs of the family (food, shelter, clothes, education of children, health, transportation). About $15.4 \%$ perceive poverty as lack of knowledge or illiteracy. Population believes that knowledge is power. That an educated person is powerful and influential and would be able to carry on profitable activities that will empower the community economically when given the necessary support thereby removing poverty from their door post. About $7.6 \%$ of the population considered poverty as "state of being lazy". When a person is lazy he/she is bound to be poor. Poverty as lack of personal possessions (farmland, livestock, good houses and etcetera) accounted for $5.1 \%$ of the respondents. Others $(3.5 \%)$ considered poverty as lack of children. In the traditional African society children are considered as wealth, and a family with many children (especially males) is respected and seen as a rich family. On the other hand, a family without child/children irrespective of his status, is seen as a poor family with no hope for tomorrow, and does not command any respect by the villagers 
Table 3 Respondents' Perception on Poverty

\begin{tabular}{|c|c|c|c|c|c|c|c|c|c|c|c|c|c|c|}
\hline \multirow{2}{*}{$\begin{array}{l}\text { Respondents' perception of poverty } \\
\text {-Lack of money to meet basic needs of } \\
\text { the family. }\end{array}$} & \multicolumn{2}{|c|}{ Kantoma } & \multicolumn{2}{|c|}{$\begin{array}{l}\text { Ampang- } \\
\text { west }\end{array}$} & \multicolumn{2}{|c|}{ Kombun } & \multicolumn{2}{|c|}{ Langai } & \multicolumn{2}{|c|}{ Pushit } & \multicolumn{2}{|c|}{ Chakfem } & \multicolumn{2}{|c|}{$\begin{array}{l}\text { All } \\
\text { settlement }\end{array}$} \\
\hline & 15 & 50.0 & 40 & 43.0 & 48 & 38.1 & 41 & 53.2 & 37 & 45.1 & 33 & 41.2 & 214 & 43.9 \\
\hline -Lack of knowledge/illiteracy & 7 & 23.3 & 21 & 22.6 & 19 & 15.1 & 9 & 11.7 & 7 & 8.5 & 12 & 15.0 & 75 & 15.4 \\
\hline $\begin{array}{l}\text {-State of being lazy } \\
\text {-Lack of possessions like farmland } \\
\text { clothes, farm, livestock, and good house }\end{array}$ & 1 & 3.3 & 5 & 5.4 & 13 & 10.3 & 5 & 6.5 & 9 & 11.0 & 4 & 5.0 & 37 & 5.1 \\
\hline among others & 3 & 10.0 & 5 & 5.4 & 5 & 4.0 & - & - & 8 & 9.8 & 4 & 5.0 & 25 & 5.1 \\
\hline -Unfavourable condition of living & 1 & 3.3 & 2 & 2.2 & 7 & 5.6 & - & - & 4 & 4.9 & 3 & 3.8 & 17 & 3.5 \\
\hline -Stage of no progress in one's life & 2 & 6.7 & 3 & 3.2 & 9 & 7.1 & 1 & 1.3 & 5 & 6.1 & 4 & 5.0 & 24 & 4.9 \\
\hline -Lack of children to inherit you & - & - & 4 & 4.3 & 4 & 3.2 & 2 & 2.6 & 3 & 3.6 & 4 & 5.0 & 17 & 3.5 \\
\hline -Others & 1 & 3.3 & 13 & 14.0 & 21 & 16.7 & 19 & 24.7 & 9 & 11.0 & 16 & 20.0 & 79 & 16.2 \\
\hline Respondents status & 17 & 56.7 & 48 & 51.6 & 73 & 57.9 & 59 & 76.6 & 51 & 62.2 & 50 & 62.5 & 298 & 61.1 \\
\hline $\begin{array}{l}\text { Poor } \\
\text { Not poor }\end{array}$ & 13 & 43.3 & 45 & 48.4 & 53 & 42.1 & 18 & 23.4 & 31 & 37.8 & 30 & 37.5 & 190 & 38.9 \\
\hline
\end{tabular}

About $43.9 \%$ of the respondents share similar view on poverty as Planning Commission of Bangladesh (PCB, 2001) which defined poverty "as a situation in which households or a person is unable to satisfy certain needs or groups of needs priori to established yardsticks".

Causes of Poverty

Table 3 shows the perceived causes of poverty in the study area.

Table 3 Causes of Poverty in the Study Area

\begin{tabular}{|c|c|c|c|c|c|c|c|c|c|c|c|c|c|c|}
\hline \multirow[t]{2}{*}{ Causes of poverty } & \multicolumn{2}{|c|}{ Kantoma } & \multicolumn{2}{|c|}{$\begin{array}{l}\text { Ampang } \\
\text { west }\end{array}$} & \multicolumn{2}{|c|}{ Kombun } & \multicolumn{2}{|c|}{ Langai } & \multicolumn{2}{|c|}{ Pushit } & \multicolumn{2}{|c|}{ Chakfem } & \multirow[t]{2}{*}{ All } & \multirow[t]{2}{*}{$\%$} \\
\hline & $\%$ & & & $\%$ & $\%$ & & $\%$ & & $\%$ & & $\%$ & & & \\
\hline $\begin{array}{l}\text {-Lack of farm input } \\
\text { due to cost of } \\
\text { procurement }\end{array}$ & 8 & 26.7 & 37 & 39.8 & 39 & 31.0 & 11 & 14.3 & 22 & 26.8 & 20 & 25.0 & 13 & 28.1 \\
\hline $\begin{array}{l}\text {-Land dispute/court } \\
\text { Case }\end{array}$ & 5 & 16.7 & 6 & 6.5 & 12 & 9.5 & 22 & 28.6 & 11 & 13.4 & 10 & 12.5 & 7 & 13.5 \\
\hline -Communal conflict & 5 & 16.7 & 8 & 8.6 & 13 & 10.3 & 8 & 10.4 & 5 & 6.1 & 5 & 6.2 & 66 & 9.0 \\
\hline $\begin{array}{l}\text {-Natural disaster such } \\
\text { as fire, flood, storm } \\
\text { drought }\end{array}$ & 1 & 3.3 & 9 & 9.7 & 12 & 9.3 & 4 & 5.2 & 2 & 2.4 & 3 & 3.8 & 44 & 6.4 \\
\hline $\begin{array}{l}\text {-Ill-health/dead of } \\
\text { bread winner }\end{array}$ & 3 & 10.0 & 7 & 7.5 & 3 & 2.4 & 1 & 1.3 & 11 & 13.4 & 2 & 2.5 & 27 & 5.5 \\
\hline $\begin{array}{l}\text { Government } \\
\text { insensitivity to the } \\
\text { needs of the ruralites }\end{array}$ & 3 & 10.0 & 3 & 3.2 & 5 & 4.0 & 9 & 11.7 & 7 & 8.5 & 9 & 11.2 & 36 & 7.4 \\
\hline -Lack of inheritance & 1 & 3.3 & 5 & 5.4 & 2 & 1.6 & 4 & 5.2 & 8 & 9.8 & 1 & 1.2 & 21 & 4.3 \\
\hline -Inheritance from parent & - & - & - & - & 2 & 1.6 & 1 & 1.3 & 1 & 1.2 & 1 & 1.2 & 5 & 1.0 \\
\hline -Witcraft & 1 & 3.3 & 2 & 2.2 & 5 & 4.0 & 2 & 2.6 & 5 & 6.1 & 2 & 2.5 & 17 & 3.5 \\
\hline -Lack of self control & 1 & 3.3 & - & - & 1 & 0.8 & - & - & - & & - & - & 2 & 0.4 \\
\hline $\begin{array}{l}\text {-Lack of good storage } \\
\text { facilities }\end{array}$ & 2 & 6.7 & 2 & 2.2 & 4 & 3.2 & 3 & 3.9 & - & & - & - & 11 & 2.3 \\
\hline $\begin{array}{l}\text {-Low price of farm } \\
\text { produce in the market }\end{array}$ & - & - & 6 & 6.5 & 3 & 2.4 & 6 & 7.8 & - & - & 5 & 6.2 & 20 & 4.1 \\
\hline $\begin{array}{l}\text {-Lack of road to } \\
\text { transport farm produce }\end{array}$ & - & - & - & - & 7 & 5.6 & 3 & 3.9 & - & - & 10 & 12.5 & 21 & 4.3 \\
\hline -Others. & - & - & 8 & 8.6 & 18 & 14.3 & 3 & 3.9 & 10 & 12.5 & 12 & 15.0 & 50 & 10.2 \\
\hline
\end{tabular}


The Table reveals that lack of farm input due to the high cost of procurement is a cause of poverty as cited by majority (28.1\%) of respondents. For instance a bag of fertilizer costs between $\$ 5,500$ and $\$ 6,000$ depending on the brand, while a bag of maize or corn is sold for between $\$ 3,500$ and $N 5,000$. This means that one bag of maize taken to the market cannot bring back home a bag of fertilizer. This has serious implications because the soil nutrient of the area is declining as a result of continuous cultivation. In almost all parts of the study area, for high yields to be possible, fertilizer must be applied to the crops at least three times. Land dispute $(13.5 \%)$ is another cause of poverty which in most cases result in court case. Another cause is EthnoReligion/Political/Crises (9.0\%). This corroborates that of Alubo (2006) in his analysis of Ethnic conflicts and citizenship crises in the Central Region of Nigeria. Other perceived causes of poverty include; occurrence of natural disaster $6.4 \%)$, ill-health and eventual death of bread winner in the family (5.5\%), superstitions ( $3.5 \%$ ), lack of good storage facilities $(2.3 \%)$ and low prices of farm produce in the market( $4.1 \%)$ among others.

\section{Conclusion}

The study discovered that bulk of the labour force fall within age bracket 50-60 years and above. This indicates that the labour force is characterized by aging labour force. The implication is diminishing returns in production as the labourforce is weak. Majority of the labour force (household heads) have large family size of 7 and above. This proportion of the population accounts for $62.5 \%$ of the respondents in the study area. This implies that large family size is a major contributor to the success of many families in the study area. Furthermore, a large proportion of the population has low level of education as most (52\%) have no formal education. On occupation, $(84.8 \%)$ of respondents are farmers. Agriculture in the study area is characterized by low output resulting to food insecurity and poverty which implies a slow pace of development in the rural areas (communities). The study concludes that the incidence of poverty is very high in the study area as more than $74 \%$ of the population is poor.

\section{Recommendations}

Arising from the above conclusion, the following recommendations are made:
* Majority of the poor are farmers. To this effect, establishing a fertilizer blending company and the provision of high yielding and disease resistant variety of seeds in the study area will be a sure way to success for these farmers.

*There is need for the diversification of the economic activities of the populace from agriculture to non-agriculture. This will no doubt increase their earnings thereby reducing the level of poverty and hence the development of the rural areas.

\section{References}

Adeyeye, V.O. (2000), Designing and Managing Poverty Alleviation programmes in Nigeria. The large project option: A paper presentated at the workshop on Poverty Alleviation Policies and Strategies organised by NCEMA/World Bank, Ibadan

Aigbokhan B.E (1991), 'Structural Adjustment Pr ogramme, Income Inequality and Poverty in Niger ia': Case study of Bendel State. African

Development.

Aigbokhan, B.E (2001), 'Poverty, Growth and Inequality in Nigeria'. AERC Research paper 102, Nairobi, Nov.2000.

Aigbokhan, B.E (2007), 'Poverty Alleviation in Ni geria: Some Macroeconomic Issues.' Nigeria

Economic society

Annual Conference Proceedings

Alubo,O.(2006), 'Ethnic Conflicts and Citizenship Crises in the Central Region, Programme on Eth nic and Federal Studies (PEFS),9-33,38-44 Canagarajah, S., Ngwaton, J and Thomas (1997), 'The Evolution of Poverty and Welfare in Nigeria, 1985-1992' Policy Research Working Paper No 7, 15 January.

Dakyes,S.P.(2007); 'Rural Labourforce Characterization in Kombun District of Mangu Local Government Area, Plateau State'. Abuja Journal of Geography and Development Vol 1 No. 2 September.pp21-32

Department for International Development (DFID, 2007), 'Tackling Rural Poverty in Developing Countries'. Report by the Comptroller and Auditor General/HC 322 session 2006-

07/14 March 2007.

Food and Agricultural Organization (FAO,2005), “ Structural Transformation to

Break Away from Rural Poverty'. Online.

Downloaded 12-09-2008 
Gustavo, A. and Stamaulis, K. (2007); 'Rural Dev elopment and Poverty Reduction: Is Agriculture sti 11 the key'? ESA working paper No 07- 02, June 2007. www.fao.org/es/esa. Iliffe, J.(1987), 'The African Poor: A History'. Cambridge, UK: Cambridge University Press. Kirubi,M.(2005); 'Rural Poverty, Decentralization and Development'. Online downloaded 11/09/2008

Krishna, A. (2004), 'Escaping Poverty and Becoming Poor: Who Gains, Who loses, and Why?' World Development 32(1),121-136. National Bureau of Statistics (NBS 2005), Poverty profile for Nigeria. 6-20pp.

NBS (2006), 'Core Welfare Indicator

Questionnaire survey, Nigeria 2006',pp 2, 69-73. NPC, (2007), 'Legal Notice on Publication of the Details of the Bread down of the National and State Provisional Totals 2006 Census. Federal Republic of Nigeria official Gazette No 24, vol. 94,15 ${ }^{\text {th }}$ May, 2007.

Obadan, M.I.(1995), 'Perspectives on Poverty in Nigeria', Paper Presented at the Workshop on Integration of Poverty Alleviation into Plans and Programmes in Nigeria organised by NCMA/World Bank,Ibadan.

Okeke, M. (2007), 'Mankind: Transiting from Poverty to Prosperity, In Economic: Conquering Poverty, Enthroning Prosperity', Zenith Economic Quarterly vol 2, No 12, September 2007.

Olayemi, J.K. (1995), 'A survey of Approaches to Poverty Alleviation', paper Presented at the workshop on Integration of Poverty Alleviation into Plans and Programmes in Nigeria organised by NCEMA/world Bank, Ibadan.

Olaniyan, O. (2003), "The Effects of Household education on Poverty in Nigeria". African Journal of Economic Policy 9(2), 77-101

Ogwuche, J. (2008), Access to physical Capital as a Panacea to Urban Poverty Reduction: A case study of OtukpoUrban Area of Benue State. ANG 50 th Annual Conference: Book of Proceedings

Ogwumike, F.O. (2000), 'Survey of Approaches to Poverty Alleviation Programmes: General Perspective', A paper presented at the Workshop on Poverty Alleviation Policies and Strategies organised by NCEMA, Ibadan.

Okunmadewa,F.,Olaniyan,O.,Yusuf,S.A.,Bankole, A.S.,Oyeranti,O.A.,Omonona,B.T.,Awoyemi,T.T, and Olayiwola,K.(2005); 'Human Capital,Instituti on and Poverty in Rural Nigeria',

Research Report submitted to AECR, Nairobi.

Omonona,

B.T.(2000), The determinant of Poverty among Fa rming Households in Kogi State, Nigeria.

Unpublished $\mathrm{PhD}$ Thesis in

'Human Capital, Institution and Poverty in Rural

Nigeria', Research Report submitted to AECR,

Nairobi.

Onibokun, A.G and Kumuyi, A.J. (1996), 'Urban poverty in Nigeria; Towards sustainable strategies for its Alleviation',CASSAD Monograph Series 10,Ibadan.

Place, A. M. and Hebinck, P. (2007),

'Understanding Rural Poverty and Investment in Agriculture: An assessment of Integrated Quantitative and Qualitative Research in Western Kenya'. World Development 35(2), 312-325.

Planning Commission of Bangladesh (PCB, 2001), 'Basic Needs Approach to Poverty Analysis and Analysis of Poverty Profiles in

Bangladesh. Sustainable Human Development Unit, 8 Jan.2001.

Ravallion, M., Shaohua C., and Prem S, (2007), 'New Evidence on theUrbanization of Global Poverty': Background Paper For The World Development Report 2008, World Bank, Washington DC.

United Nation Economic Commission of Africa (UNECA, 2005), 'African Agricultural

Performance in Perspective:

Constraints, Achievement and Impact of Multilateral Trade Reforms'.In Mutual Review of Development Effectiveness In The Context of NEPAD, Addis Ababa.

World Bank (1995), 'Nigeria: Poverty in the midst of Plenty: The Challenge of Growth with Inclusion.' World Bank Poverty Assessment Report No 147334, Washington D.C.

World Bank (2000), 'World Development Report 2000/1 Draft copy', Washington.

World Bank Report, (2001); "World Faith

Development Dialoque1999: A different

Perspective on Poverty and Development". Comment on World Development Report 2000/20001 London.

Yusuf, S.A. (2000), 'Institutional Framework For Poverty Alleviation Programmes in Nigeria'; Paper Presented at the NCEMA Workshop on Poverty Alleviation Policies and Strategies. 